\title{
BETWEEN HOT ROCKS AND DRY PLACES: THE STATUS OF THE DIXIE VALLEY TOAD
}

\author{
Matthew J. Forrest ${ }^{1,3}$, Josefin Stiller ${ }^{1}$, Tim L. King ${ }^{2}$, and Greg W. Rouse ${ }^{1}$
}

\begin{abstract}
In Dixie Valley, Nevada, an isolated population of toads has been the subject of proactive conservation measures by the Nevada Department of Wildlife and the U.S. Fish and Wildlife Service since 2008 due to concerns about potential habitat degradation resulting from exploitation of nearby geothermal energy resources. These toads appear to belong within the Anaxyrus boreas species group but are commonly referred to as Dixie Valley toads (DVTs). The DVT is currently confined to an extremely narrow habitat range (370 ha) that is geographically isolated from any other A. boreas population. In this study, genetic variations in mitochondrial genes and 11 microsatellite loci were used to assess the affinities of DVTs in relation to members of the A. boreas species group. We compared results from DVTs with previously published data spanning much of the range of A. boreas in the United States and new data from a nearby toad population within Dixie Valley. Data from both mitochondrial DNA and microsatellites placed DVTs inside the A. boreas species group. In particular, DVTs fell into a cluster of A. boreas from Washington and California, along with other species from the A. boreas species group, namely A. nelsoni, A. canorus, and A. exsul. Genetic differentiation of DVTs was lowest between A. boreas populations in Washington and California. However, allele frequencies were significantly different between DVTs and all other populations, including a nearby locality within Dixie Valley. This genetic differentiation, along with the DVT's geographical isolation and restricted habitat, warrants recognition of the DVT as a distinct management unit.
\end{abstract}

Resumen.-Desde el 2008 en el Valle Dixie, en Nevada, Estados Unidos, el Departamento de Fauna de Nevada y del Servicio de Pesca y Fauna de los Estados Unidos ha tomado medidas proactivas de conservación de una población aislada de sapos, debido a la preocupación de una posible degradación del hábitat resultado de la explotación de los recursos energéticos geotérmicos cercanos. Estos sapos parecen pertenecer al grupo de especies de Anaxyrus boreas, pero se los conoce comúnmente como sapos del Valle Dixie (DVT, por sus siglas en inglés). Actualmente, los DVT están confinados a un rango de hábitat extremadamente estrecho (370 hectáreas), geográficamente aislado de otras poblaciones de A. boreas. Se utilizaron las variaciones genéticas en los genes mitocondriales y 11 loci microsatélitales para evaluar las afinidades de los DVT en relación con los miembros de los grupos de la especie A. boreas. Comparamos a los DVT con datos previamente publicados de gran parte del rango de A. boreas en los Estados Unidos, con datos nuevos de una población cercana de sapos en el Valle Dixie. Tanto el ADN mitocondrial como los microsatélites colocan a los DVT dentro del grupo de A. boreas. En particular, los DVT se incluyeron dentro de un grupo de A. boreas de Washington y de California junto con otras especies del grupo de A. boreas, como, A. nelsoni, A. canorus y A. exsul. La diferenciación genética de los DVT fue la menor entre las poblaciones de A. boreas en Washington y en California. Sin embargo, las frecuencias alélicas fueron significativamente diferentes entre los DVT y todas las demás poblaciones, incluyendo la de una localidad cercana dentro del Valle Dixie. Esta diferenciación genética, junto con su aislamiento geográfico y la restricción del hábitat, avala el reconocimiento de los DVT como una unidad de manejo diferente.

Dixie Valley toads (DVTs) are morphologically unusual toads with an extremely narrow distribution (approximately 370 ha) within Dixie Valley, Churchill County, Nevada (Fig. 1). Although the toad is not formally described, it has been suggested that the DVT represents a separate species (Wildlife Action Plan Team 2012, Rose et al. 2015), and the Nevada Department of Wildlife (NDOW), the Bureau of Land Management (BLM), and the U.S. Fish and Wildlife Service (USFWS) currently consider it an important and potentially vulnerable population (K. Urquhart, personal communication 2016). These agencies are concerned that exploitation of geothermal and groundwater resources within Dixie Valley may cause disturbances to essential wetland habitat for DVTs (BLM, CCD 2013, BLM 2014). The DVT occurs within the range of Anaxyrus boreas (Fig. 2), and shares morphological similarities with other toads from the A. boreas species group (Wright and Wright 1949, Stebbins 2003, Dodd 2013). Note that Anaxyrus members are treated as being in the genus Bufo

\footnotetext{
${ }^{1}$ Scripps Institution of Oceanography, University of California San Diego, La Jolla, CA

${ }^{2}$ Leetown Science Center, U.S. Geological Survey, Kearneysville, WV.

${ }^{3}$ E-mail: matthewforrest@gmail.com
} 


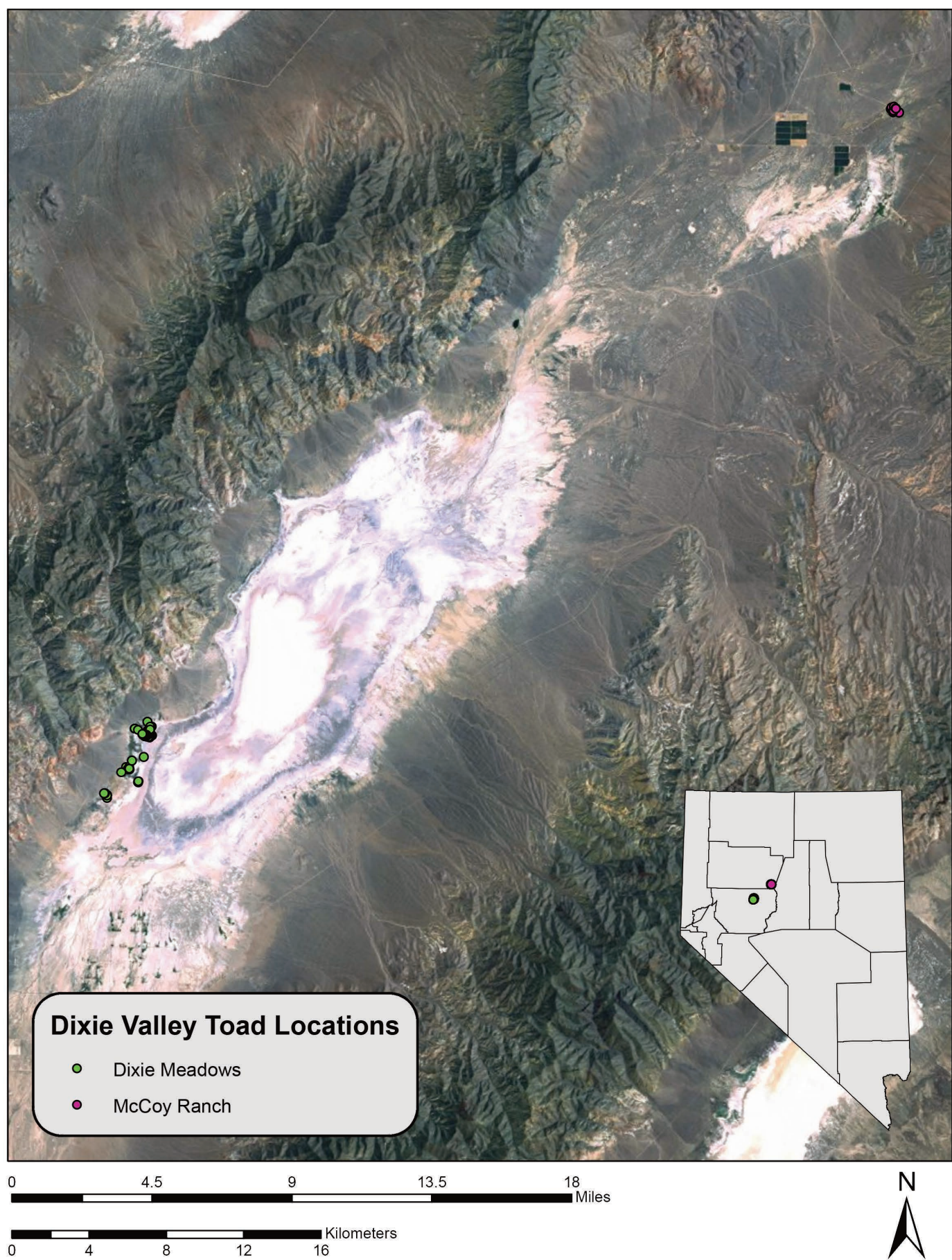

Fig. 1. Satellite map of Dixie Valley, Nevada, area showing locations of sampling sites for Dixie Valley toads and toads from McCoy Ranch. Courtesy of J. Harter, USFWS. 


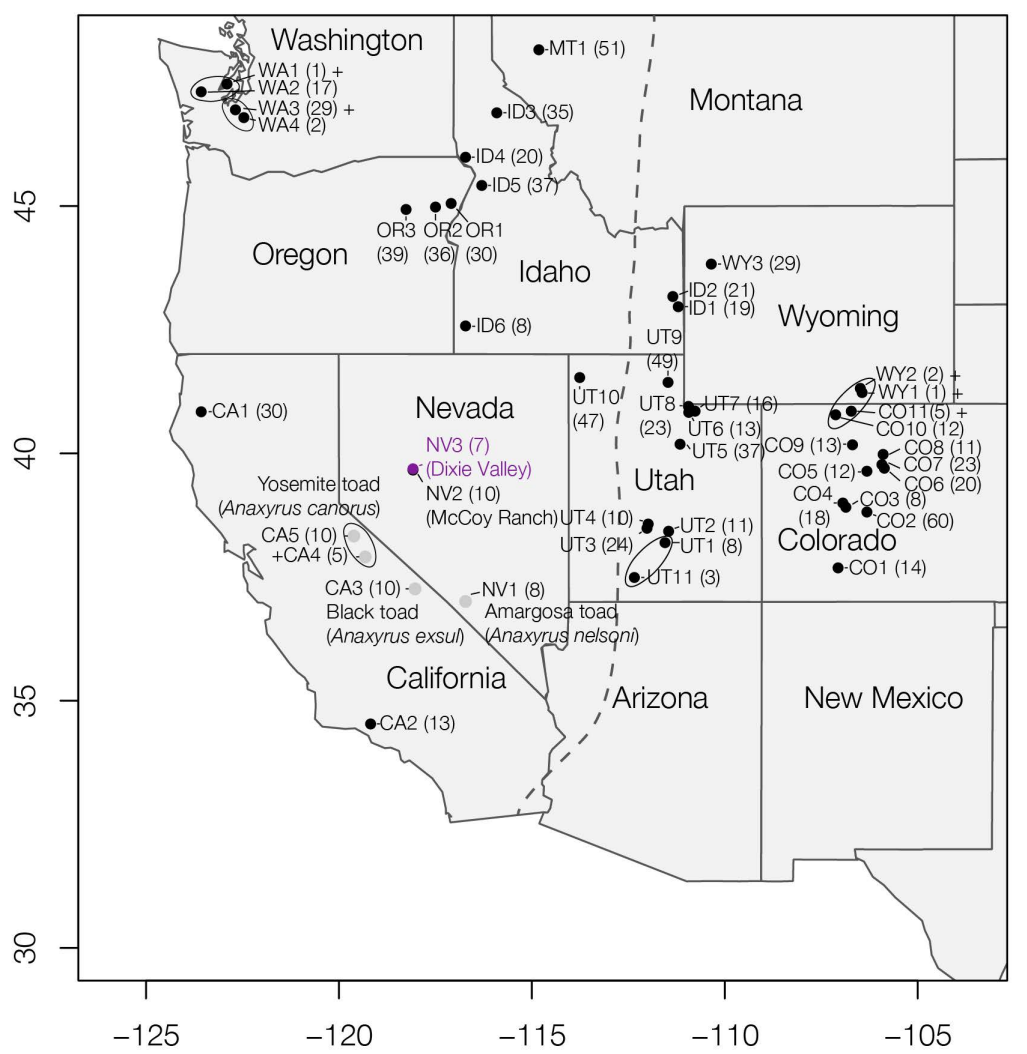

Fig. 2. Map of the sampled populations of the A. boreas species group, mainly from Switzer et al. (2009). New genotypes are from 2 populations in Nevada: toads from McCoy Ranch (NV2) and Dixie Valley toads (NV3, in purple). The dashed line corresponds to the main split in the microsatellite data as indicated through the Structure assignment (see Fig 6A).

by some authors (see Pauly et al. 2009 for further discussion).

Currently, DVTs rely on 4 wetlands fed by geothermal springs, the only perennial sources of habitable freshwater in their native habitat (Fig. 1). The surrounding soils are primarily very dry, alkaline playa deposits covered with salt crusts (Garcia et al. 2014), which likely serve as impassable barriers for amphibians. Temperatures on the Dixie Valley floor range from $<0{ }^{\circ} \mathrm{C}$ in winter to $>40{ }^{\circ} \mathrm{C}$ in summer, with daily fluctuations often exceeding $20^{\circ} \mathrm{C}$. Mean annual precipitation from 2006 to 2011 was $102 \mathrm{~mm}$ (Garcia et al. 2014). The geographically closest population of $A$. boreas toads outside of Dixie Valley is approximately $30 \mathrm{~km}$ to the southwest in the Stillwater Wetlands (K. Urquhart, personal communication 2016). However, the Stillwater Range, which is $110 \mathrm{~km}$ long and reaches heights of 1000$2500 \mathrm{~m}$, separates the Stillwater Wetlands from Dixie Valley. Water is scarce, as there are no perennial streams in the Stillwater Range; therefore, recent connectivity between the DVT and this A. boreas population is very unlikely.

The Anaxyrus boreas (Baird and Girard 1852) species group comprises 2 subspecies that are broadly distributed across western North America and 3 other species with localized distributions (Fig. 2; Stebbins 2003, Goebel et al. 2005, 2009, Dodd 2013). The western toad, Anaxyrus boreas (Baird and Girard 1852), occurs from the east slope of the Rocky Mountains to the Pacific Ocean, and from northern Baja California, Mexico, to Alaska and the Yukon of Canada (Goebel et al. 2009, Dodd 2013). The subspecies Anaxyrus boreas boreas (Baird and Girard 1852), commonly referred to as the boreal toad, occupies most of this range. The second subspecies, the California toad, Anaxyrus boreas halophilus (Baird and Girard 1853), occurs from northern California south to Baja California, Mexico. 
The 3 other narrowly distributed Anaxyrus species also considered by Goebel et al. (2009) to be members of the A. boreas species group are A. exsul (Myers 1942), A. nelsoni (Stejneger 1893), and A. canorus (Camp 1916). The black toad, A. exsul, occurs only in Deep Springs Valley in east central California (Myers 1942, Fellers 2005). Similarly, the Amargosa toad, A. nelsoni, occupies a very limited range, and is currently only found in the Amargosa River drainage of southwestern Nevada (Altic and Dodd 1987, Goebel et al. 2005, Forrest et al. 2015). The Yosemite toad, A. canorus, is narrowly distributed at high elevations in the Sierra Nevada in California, and is sympatric with $A$. boreas at the northern end of its distribution (Karlstrom 1958, 1962, Davidson and Fellers 2005, Goebel et al. 2009). Information on the geologic history of the region suggests that populations of $A$. boreas may have become separated within isolated drainage basins during the Pleistocene (Hovingh 1997, Reheis et al. 2002). These vicariant barriers have been proposed as the mechanisms that caused allopatric speciation in the A. boreas species group (Stebbins 2003, Goebel et al. 2009, Noles 2010). Dixie Valley is an arid, closed drainage basin that is surrounded by mountains reaching heights of $2500 \mathrm{~m}$ and that has been hydrologically isolated from any other body of water since at least the Pleistocene (Caskey and Ramelli 2004). Therefore, the DVT has potentially been isolated from any other population of A. boreas toad for thousands of years.

Here, we used genetic analyses to assess the affinities of DVTs in relation to other members of the A. boreas species group. We compared results from DVTs with previously published genetic data spanning much of the range of A. boreas in the United States (Wright and Wright 1949, Stebbins 2003, Goebel et al. 2009, Switzer et al. 2009, Dodd 2013) along with new data from a small population of toads within Dixie Valley at nearby McCoy Ranch (about $50 \mathrm{~km}$ away; Fig. 1). NDOW biologists first encountered the McCoy Ranch toad population in 2009 during explorations of other potentially habitable spring systems within Dixie Valley, but residents of McCoy Ranch report having seen the toads there since the 1960s (K. Urquhart, personal communication 2016).

\section{Methods}

We collected samples from Dixie Valley toads (site NV3 in Fig. 2) and from toads in a small population at nearby McCoy Ranch (site NV2). The latter were included in the analyses because of their proximity to the DVT habitat (about $50 \mathrm{~km}$ away; Fig. 1); this is the only other known population of $A$. boreas toads within Dixie Valley (K. Urquhart, personal communication 2016). We integrated new sequence data for mitochondrial genes and microsatellite genotypes from these samples with previously published data from the $A$. boreas species group (Simandle et al. 2006, Goebel et al. 2009, Switzer et al. 2009).

Targeted population surveys were conducted in high-density toad habitat within Dixie Meadows from 2009 to 2015 by researchers from the Nevada Department of Wildlife and U.S. Fish and Wildlife Service (see Forrest et al. 2013 for details). At McCoy Ranch, the small population of toads was also surveyed near the drainage of a geothermal spring and along associated irrigation ditches and canals. Tadpoles and toeclips from adult toads were collected in 2012 and 2015 for molecular analysis. When tadpoles were used, only one sample from the same vicinity was collected in order to minimize the chances of analyzing siblings. Toads were caught by hand at active breeding sites to determine sex and measure lengths, but toads in amplexus were avoided. Juvenile and adult males were distinguished based on secondary sexual traits (i.e., presence of nuptial pads and production of release calls). Snout-vent lengths (SVL) were determined by using handheld metric rulers or calipers to measure from the snout of the toad to its cloaca (vent). The SVLs from adult DVTs and adult toads from McCoy Ranch were compared using a 2-sample 2-tailed $t$ test with unequal variance. Morphologies and dorsal coloration patterns were also documented during these surveys, and digital images of specimens were obtained. We compared coloration and size of DVTs and McCoy Ranch toads to previously published accounts of the A. boreas species group (Wright and Wright 1949, Stebbins 2003, Dodd 2013).

Mitochondrial Sequencing

We sequenced 8 DVT samples (DS1, DS2, DM1, DM2, DM3, DM4, DM5, and DM6) 
and 3 samples of McCoy Ranch toads (MC6, MC7, and MC9) for mitochondrial fragments. Genomic DNA was extracted from samples using the DNeasy Blood and Tissue kit (Qiagen Inc., Valencia, CA) according to the manufacturer's protocols. Sequences of the mitochondrial control region (CR) and cytochrome oxidase I (COI) were obtained using primers described in Goebel et al. (2009). Amplification reaction mixtures included the following: 12.5 $\mu \mathrm{L}$ of GoTaq Green Master Mix (Promega Corporation, Madison, WI), $1 \mu \mathrm{L}$ of each primer $(10 \mu \mathrm{M})$, and $1-3 \mu \mathrm{L}$ of DNA template in a total volume of $25 \mu \mathrm{L}$. Reaction mixtures were heated to $94{ }^{\circ} \mathrm{C}$ for $2 \mathrm{~min}$, followed by 35 cycles of $94{ }^{\circ} \mathrm{C}$ for $30 \mathrm{~s}$; primer pair-specific annealing temperatures for $30 \mathrm{~s}$; and $68^{\circ} \mathrm{C}$ for $45 \mathrm{~s}$; followed by a final extension of $7 \mathrm{~min}$ at $72{ }^{\circ} \mathrm{C}$ in an Eppendorf Mastercycler. PCR amplifications were purified using ExoSAP-IT (Affymetrix, Inc., Santa Clara, CA) and then sequenced by Invitrogen Corp (Alabama).

The new COI (Genbank accession numbers KY706468-KY706478) and CR data (Genbank accession numbers KY706479-KY706488) were combined and added to a relevant subset of the data from Goebel et al. (2009), which included data from the A. boreas species group from a wide geographic range. These data were analyzed phylogenetically using a maximum likelihood (ML) procedure implemented in RAxML-VI-HPC (Stamatakis 2006) with the RAxML GUI (Silvestro and Michalak 2012). Data were partitioned by gene (each under the GTR + I + G model), with support assessed via the thorough bootstrap option (10 runs, 1000 pseudoreplicates). Outgroup terminals from Goebel et al. (2009) were used to root the tree and included toad species from Anaxyrus, and the genera Rhinella and Incilius. There were no CR data for these terminals so the root position was established by the COI data alone.

\section{Microsatellite Genotyping}

The multilocus genotypes from 8 DVTs and 10 McCoy Ranch toads were analyzed in relation to data from 890 individuals within the $A$. boreas group from Switzer et al. (2009). One individual failed to amplify for most markers and was excluded from the analysis, leaving a total of 7 DVT samples. Seven sampling sites had too few individuals ( $\leq 5$ individuals) to calculate population statistics and were there- fore grouped with the geographically closest locality (as shown in Fig. 2). We used the same microsatellite markers (Simandle et al. 2006) as Switzer et al. (2009) but excluded one nonamplifying locus (Bbr17), leaving 11 microsatellite loci.

Forward primers used to amplify the microsatellite loci were fluorescently labeled (6-FAM, HEX, NED) for visualization. PCR reactions $(25 \mu \mathrm{L})$ contained $2.5 \mu \mathrm{L}$ PCR buffer, $1.2 \mu \mathrm{L}$ $\mathrm{MgCl}_{2}(25 \mathrm{mM}), 0.7 \mu \mathrm{L}$ dNTPs $(1 \mathrm{mM}), 1.2 \mu \mathrm{L}$ of each primer $(10 \mu \mathrm{M}), 0.125 \mu \mathrm{L}$ Taq Polymerase (New England Biolabs, USA), 1-2 $\mu \mathrm{L}$ template DNA, and nuclease-free water. Amplification followed Switzer et al. (2009). Loci of similar size and different fluorophores were multiplexed and analyzed together. Each sample received $10 \mu \mathrm{L}$ of formamide loading dye and $4 \mu \mathrm{L}$ was electrophoresed with a size standard (MegaBACE ET550-R, Amersham Biosciences) on a 5\% denaturing urea-polyacrylamide gel $(33 \times 39 \mathrm{~cm})$. Gels were scanned using a Typhoon 8600 Scanner (Amersham Pharmacia Biotech). Alleles were scored manually with the aid of the ImageQuant software (Amersham Pharmacia Biotech).

Genetic Diversity and Genetic Associations of the Dixie Valley Toad

Genetic diversity was calculated in GenoDive v. 2.0 (Meirmans and Van Tienderen 2004) as the number of alleles $(A)$, the frequencyweighted effective allele number $\left(A_{\text {eff }}\right)$, and expected heterozygosities $\left(H_{\mathrm{e}}\right)$. GenoDive was used to measure population differentiation of the DVT and toads from McCoy Ranch in relation to other populations from the $A$. boreas species group using pairwise $F_{\mathrm{ST}}$ with 1000 permutations of individuals among populations to assess statistical significance of differences in allele frequencies. We calculated Nei's $D_{\mathrm{A}}$ distances between populations and created a neighbor-joining tree in Poptreew (Takezaki et al. 2014).

The existence of distinct genetic groups based on the multilocus data was examined using Structure v. 2.3 (Pritchard et al. 2000). The software uses genotypic data to cluster individuals into $K$ groups. We conducted a series of 20 independent runs testing $K=$ $1-30$, each consisting of 100,000 steps after a burn-in of 10,000 steps. The Clumpak webserver (Kopelman et al. 2015) was used to average over multiple runs and the best $K$ 


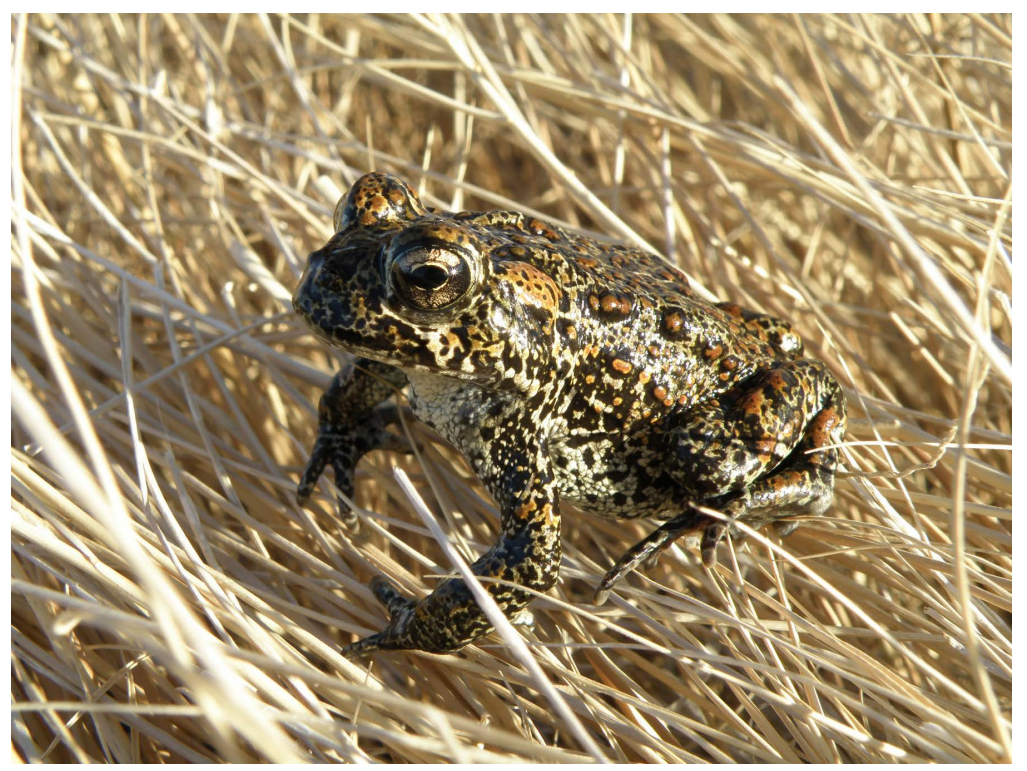

Fig. 3. An adult Dixie Valley toad sampled in 2009 from Dixie Meadows. Photo credit: K. Urquhart; used with permission.

was chosen using the StructureHarvester webserver (Earl and vonHoldt 2012) based on $\Delta K$ (Evanno et al. 2005). The analyses were conducted on the full data set and on a subset focused on the western part of the range.

\section{RESUlTS}

Dixie Valley toads (DVTs) share morphological characteristics with other toads from the A. boreas species group (Fig. 3; Wright and Wright 1949, Stebbins 2003, Dodd 2013): cranial crests are absent, pupils are horizontal, parotoid glands are oval shaped, and a lightcolored middorsal stripe is present. However, DVTs are smaller than most A. boreas toads. DVTs also have unusual dorsal coloration patterns that are typically bright yellow to green or cream colored and mottled with green, black, or brown. Parotoids are prominent and bright yellow or cream-colored with darker spots, and warts are large and reddish (Fig. 3). Toads from $\mathrm{McCoy}$ Ranch are larger and distinctly different in appearance from the DVT, with olive to dark brown/black dorsal coloration and large black or brown warts. However, like the DVT, cranial crests are absent, pupils are horizontal, parotoid glands are oval shaped, and a lightcolored middorsal stripe is present (Fig. 4).

Adult DVTs are significantly smaller than adult McCoy Ranch toads (2-sample 2-tailed $t$ test, with unequal variance: $P<0.001)$. The mean SVL of all DVTs measured was $49.9 \mathrm{~mm}$ (range 27-68 mm, $n=277$ ); the mean SVL of adult DVTs with determinable sex was $52.1 \mathrm{~mm}$ ( $n=203,56$ juveniles and 18 individuals of unknown sex excluded); the mean SVL of adult male DVTs was $51.6 \mathrm{~mm}(n=165)$; and the mean SVL of adult female DVTs was $54.3 \mathrm{~mm}$ $(n=38)$. The mean SVL of all adult McCoy Ranch toads measured was $73.5 \mathrm{~mm}$ (range $44-88 \mathrm{~mm}, n=31$ ); the mean SVL of adult male McCoy Ranch toads was $74.1 \mathrm{~mm}(n=$ 25); the mean SVL of adult female McCoy Ranch toads was $70.7 \mathrm{~mm}(n=6)$. The primary reason we measured fewer female DVTs and McCoy Ranch toads was because many of the females that we encountered were actively mating and therefore we avoided disturbing them. Female DVTs were often observed in "mating balls," with 3-5 males attempting amplexus simultaneously.

\section{Mitochondrial DNA Analyses}

There was very little mtDNA sequence difference for the DVTs or McCoy Ranch toads analyzed here with respect to the range of $A$. boreas sequences presented by Goebel et al (2009). The maximum likelihood phylogenetic analysis of the combined CR and COI data (Fig. 5) provides no evidence to support the hypothesis that the DVT is a distinct species 


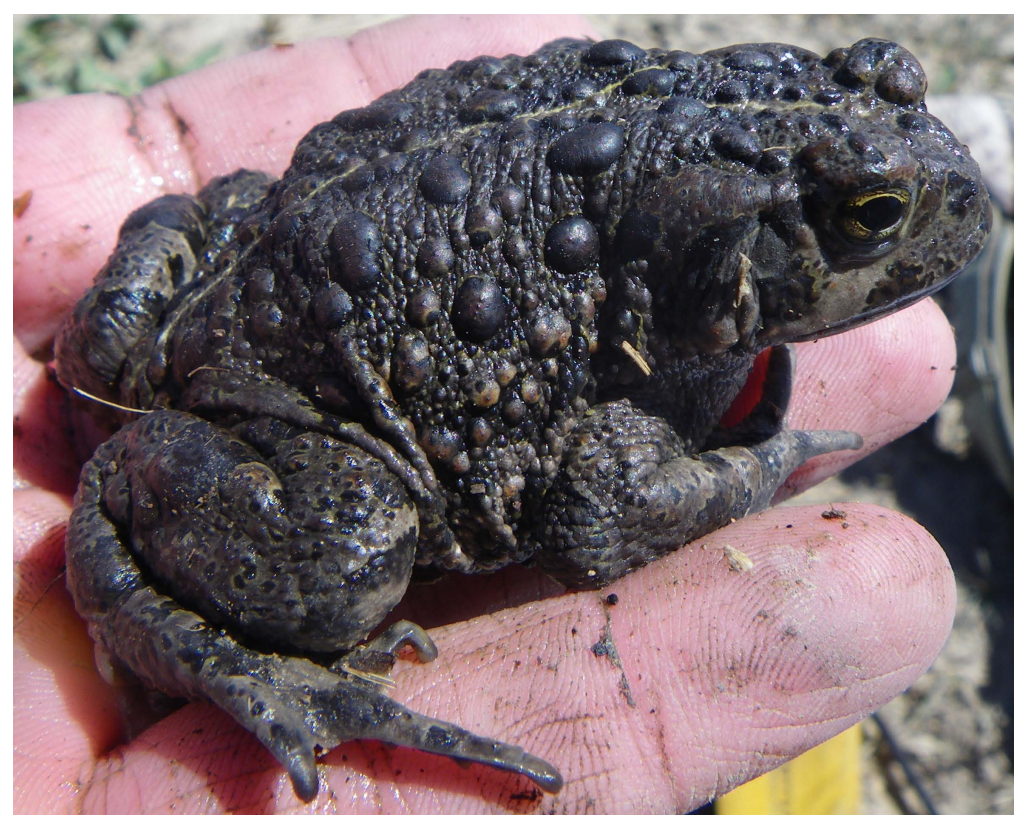

Fig. 4. An adult toad sampled in 2009 from McCoy Ranch. Photo credit: K. Urquhart; used with permission.

or subspecies. Instead, the DVT forms part of the well-supported North Western A. boreas clade identified in Goebel et al. (2009: fig. 5). In fact, 6 of the DVT samples (DM1, DM3, DM4, DM6, DS1, and DS2) that we analyzed are identical to $A$. boreas sequences from Beaverhead County, Montana (BB35BEMT in fig. 5 of Goebel et al. 2009). One DVT sequence (DM5) is identical to an A. boreas sequence from Ravalli County, Montana (BB01RCMT in fig. 5 of Goebel et al. 2009). The 3 sequences from McCoy Ranch toads (MC6, MC7, and MC9) are identical to each other and unique with respect to any of the A. boreas sequences published by Goebel et al. (2009). On the maximum likelihood tree (Fig. 5), these samples are most closely related to A. canorus and an A. boreas specimen from Oregon.

\section{Microsatellite Analyses}

DVTs showed healthy levels of genetic diversity based on microsatellite genotypes (average effective number of alleles across loci $A_{\text {eff }}=2.87$ ), well within the range of other populations of the $A$. boreas species group (range $A_{\text {eff }} 1.26-7.01$, average across all populations $=2.81$; for genetic diversities of all localities, see Supplementary Material 1).
Similarly, the DVT population had an expected heterozygosity of $H_{\mathrm{e}}=0.60$, which was above the overall average of $H_{\mathrm{e}}=0.50$ for the species group (range 0.16-0.83; Supplementary Material 1). In comparison, the diversity estimates for the geographically close McCoy Ranch toad population were at the lower end $\left(A_{\text {eff }}=1.71, H_{\mathrm{e}}=0.33\right)$.

One private allele was found in the DVTs (locus Bbr87b) and in the toads from McCoy Ranch (locus Bbr16). However, the majority of DVT alleles were shared with some other population from the A. boreas species group. Nonetheless, the DVT population showed significant differences in the frequencies of alleles compared with all other populations $\left(F_{\mathrm{ST}} \geq 0.151, P<0.001\right.$; Supplementary Material 2). Genetic differentiation between the DVT population and the geographically closest sampling locality at McCoy Ranch, only about $50 \mathrm{~km}$ away, was high $\left(F_{\mathrm{ST}}=0.406\right)$. The geographically next-closest population found in southern Idaho, showed moderate differentiation (ID6, $F_{\mathrm{ST}}=0.210$ ), and differentiation increased going northwards in Idaho and Oregon. The closest locality to the east found in Utah showed lower differentiation (UT10, $\left.F_{\mathrm{ST}}=0.264\right)$ than populations further east in Utah and Colorado $\left(F_{\mathrm{ST}} \geq 0.323\right)$. 


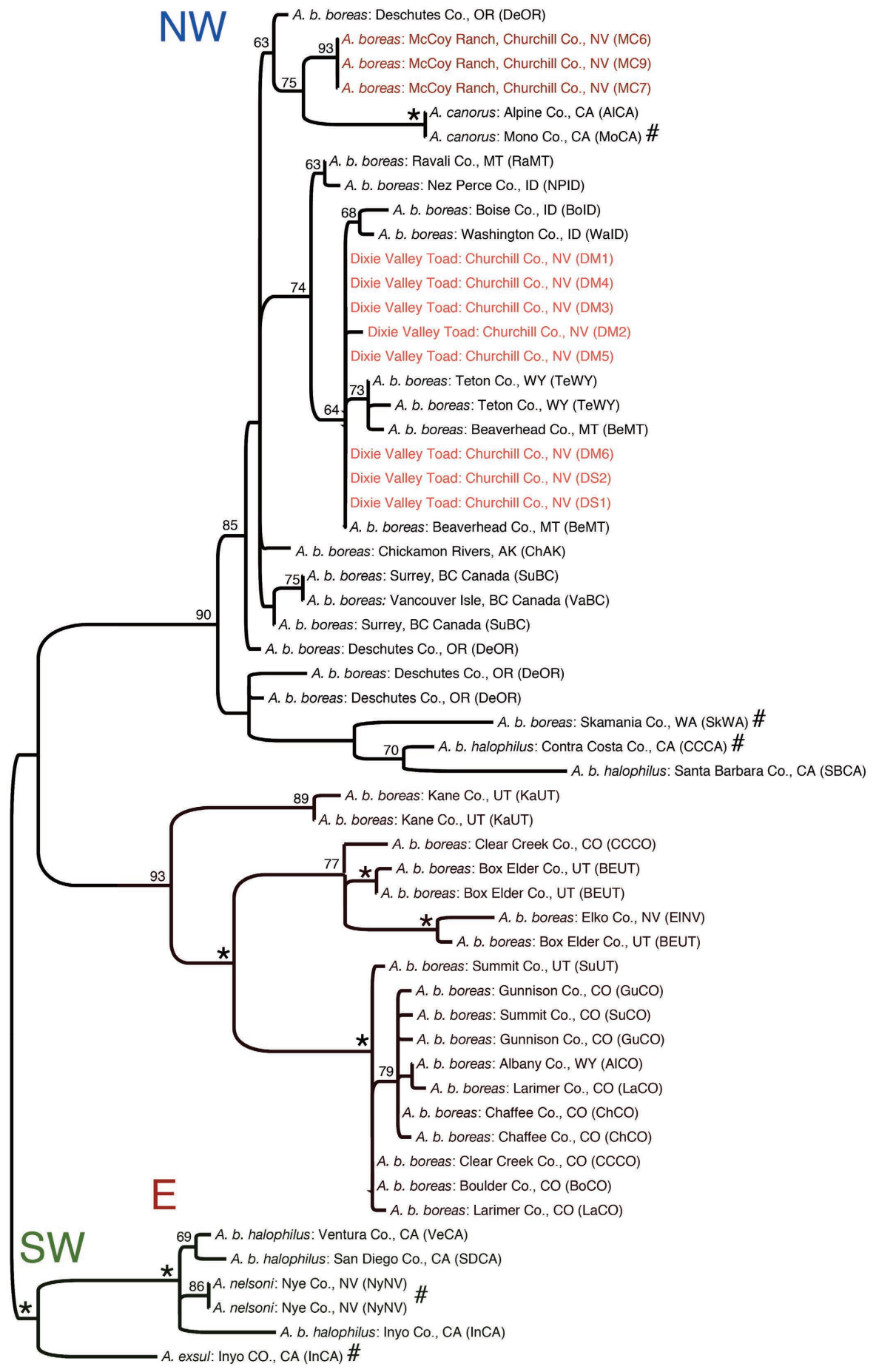

Fig. 5. Maximum likelihood analysis of the mitochondrial control region and COI data combined with the various toad outgroups (for which there was only COI data) to "root" the tree. The numbers represent bootstrap support, with asterisks (*) indicating values $\geq 95 \%$. Geographic regions are those used by Goebel et al. (2009). The pound symbol (\#) indicates the specimens from nearest the type localities for the respective nominal species/subspecies. 
Accordingly, the highest differentiation of the DVT population was observed further east against a population in Colorado $\left(\mathrm{CO} 9, F_{\mathrm{ST}}=\right.$ 0.586). These patterns did not hold toward the geographically distant populations of northern A. boreas in Washington and Montana, which had the lowest differentiation values $\left(F_{\mathrm{ST}} \leq\right.$ 0.164 and $F_{\mathrm{ST}}=0.171$, respectively). Similarly, the DVT had closer affinities to the $A . b$. halophilus populations in the coastal regions of California (CA1, CA2, $F_{\mathrm{ST}} \leq 0.223$ ) than to the spatially closer members of the A. boreas species group in California and Nevada (A. canorus, A. nelsoni, A. exsul; $F_{\mathrm{ST}} \geq 0.340$ ).

Individual clustering through Structure detected 2 clusters (Evanno method), separating populations within the western part of the range from populations within the eastern part (see dashed line in Fig. 2). The DVT fell into the western cluster with populations from Montana, western Idaho, Washington, Oregon, California, and Nevada (Figs. 2, 6A, 6B). This western group also comprised the 3 species A. canorus, A. nelsoni, and A. exsul, and also A. boreas from Washington and Oregon and A. b. halophilus from coastal California. Structure analysis focusing only on this western group detected 2 clusters, grouping DVTs with A. boreas from Washington, California, and Nevada and with the 3 species $A$. canorus, A. nelsoni, and A. exsul (Fig. 6B). The DVT population never distinctly separated from the other groups, even with $K=30$.

The broad split into eastern and western groups (dashed line in Fig. 2) was also observed in the neighbor-joining tree of Nei's $D_{\mathrm{A}}$ distances (Fig. 6C). The DVT was part of a western group comprising the species of the A. boreas group (A. canorus, A. nelsoni, A. exsul), but was also close to several members of A. boreas, particularly toads from McCoy Ranch (NV2) and samples from coastal California and Washington (Fig. 6C).

\section{Discussion}

Our mitochondrial DNA (mtDNA) and microsatellite data provide no clear evidence that Dixie Valley toads (DVTs) represent a distinct species or subspecies. The mitochondrial sequences reveal a reasonably well-supported clade with sequences obtained from A. boreas specimens of the northwestern group from Goebel et al. (2009). Additionally, according to our mtDNA results the toads from McCoy Ranch are more closely related to populations of A. canorus from Alpine and Mono Counties of California than to any other populations in the A. boreas species group (Fig. 5).

Our microsatellite analyses show that DVTs group with a cluster of samples of $A$. boreas from Washington State and A. b. halophilus from coastal California, along with the other species within the A. boreas species groupA. exsul, A. nelsoni, and A. canorus (Fig. 6A, B). These populations form a larger group of western populations within the A. boreas species complex that also comprises populations in Montana, western Idaho, and Oregon (Fig. 2). This nesting among A. boreas populations from the western United States is also found consistently in the neighbor-joining tree of Nei's $D_{\mathrm{A}}$ distances, Structure analyses (Fig. 6), and $F_{\text {ST }}$ values, suggesting recent shared ancestry.

However, these results should not be interpreted to mean that the DVT is currently exchanging with any of these populations. High allele frequency $\left(F_{\mathrm{ST}}>0.151\right)$ differences with all other populations indicate that DVTs are not currently interbreeding with any other A. boreas species group populations, which is consistent with the geographical isolation of Dixie Valley. While most alleles from the DVT are shared with some other population of the species group, one private allele was found, supporting a certain degree of reproductive isolation. Even the toad population from McCoy Ranch, only about $50 \mathrm{~km}$ away, shows a high differentiation value $\left(F_{\text {ST }}\right.$ $=0.406$ ), indicating prolonged isolation of these 2 populations from each other or independent colonization of Dixie Valley by 2 A. boreas lineages. The high $F_{S T}$ values are in line with values observed for $A$. boreas across its range and reveal relatively little gene flow between populations (Switzer et al. 2009). These results indicate that the DVT should be recognized as a distinct management unit (sensu Moritz 1994, Palsbøll et al. 2007).

Conservation efforts below the level of species are often necessary to protect intraspecific diversity, which may be critical to current and future adaptive evolutionary potential (Shaffer et al. 2015). Genetic data should not be considered independently of ecological, geographical, and other life history differences when considering the species 
(a) $\mathrm{K}=2$ (All data)
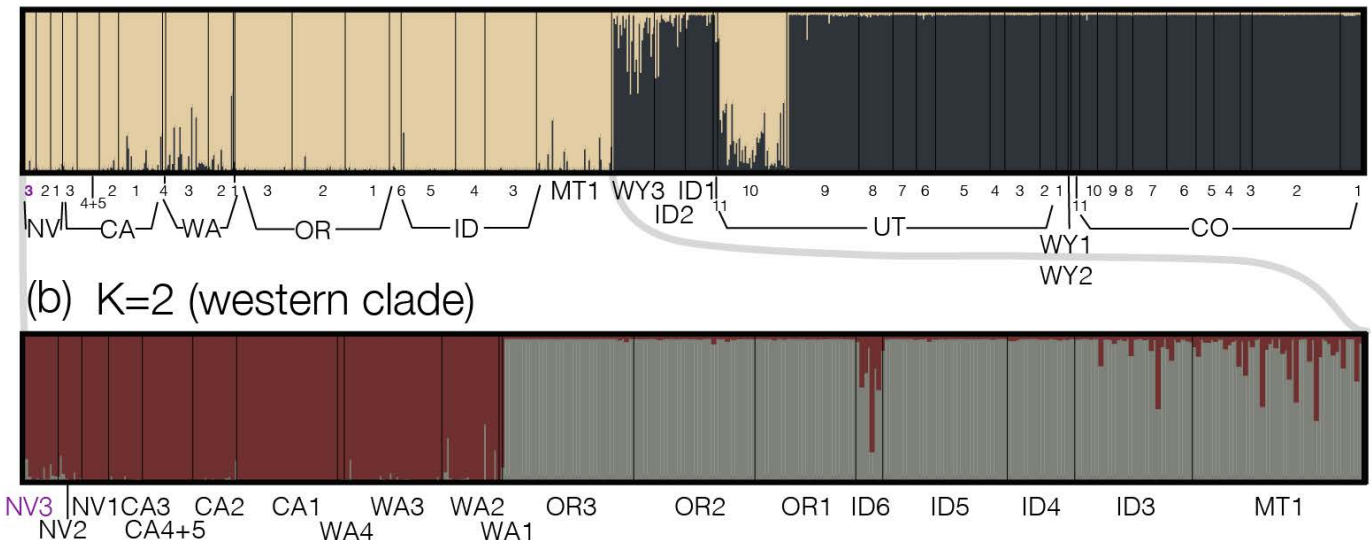

(c) Nei's $D_{A}$ distance

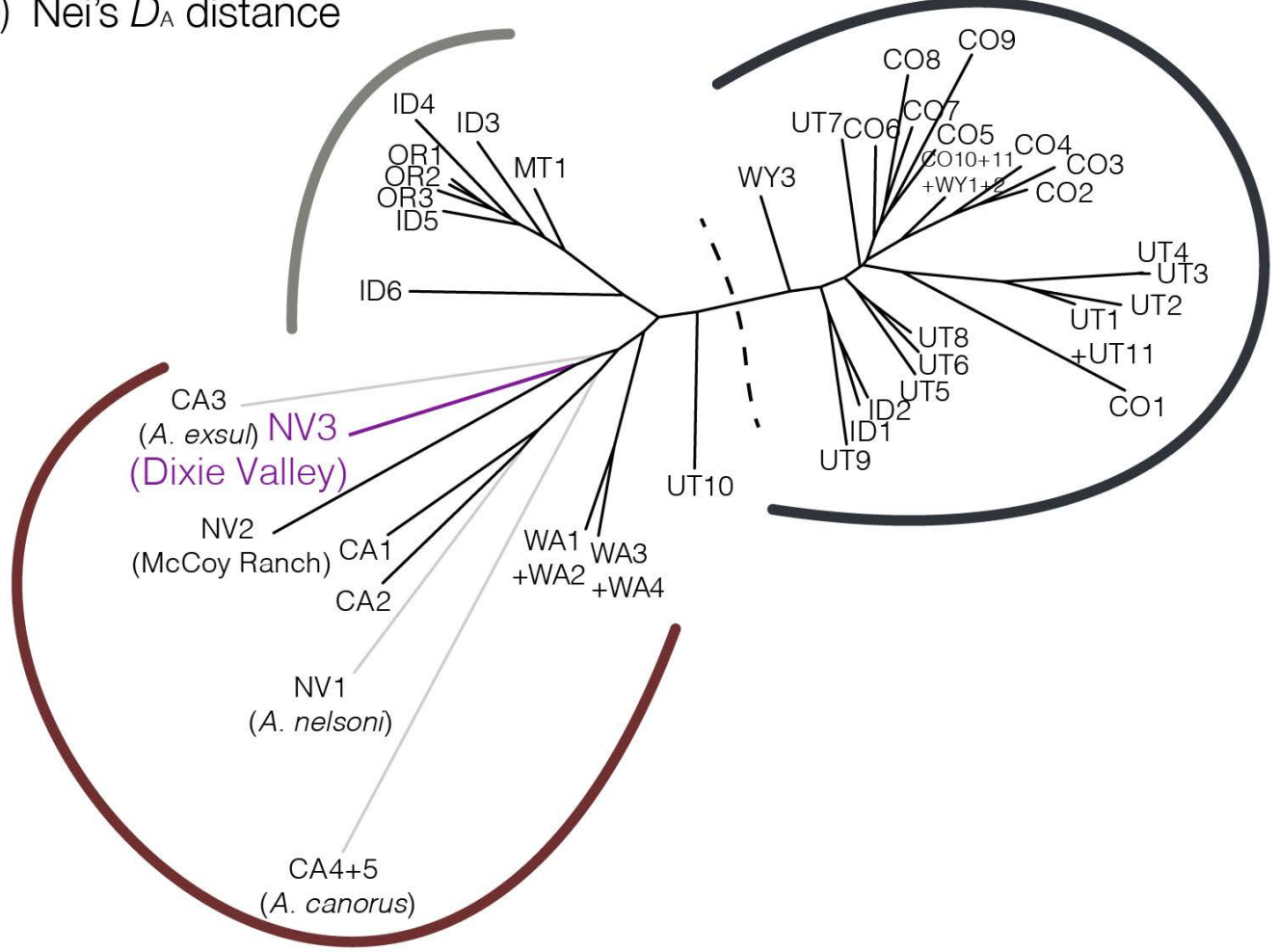

Fig. 6. (A) Individual assignment through Structure for the optimal $K=2$. (B) Individual assignment for a $K=2$ using a subset of the data from panel A. (C) Unrooted neighbor-joining tree based on Nei's $D_{\mathrm{A}}$ distances between population pairs. Three main clusters are recognized.

designations within the A. boreas species group (Shaffer et al. 2000, Goebel et al. 2009, Switzer et al. 2009). Conservation management decisions should be based on all available data because some traits reflected in morphological differences may evolve, or be detected, prior to genetic variation, particularly in mtDNA (Fallon 2007). Morphological characters that distinguish some taxa from the A. boreas species group are obvious and striking, and the DVT displays unusual coloration compared with other A. boreas toads (Fig. 3). 
Moreover, adult DVTs (average SVL $=51.2$ $\mathrm{mm}$ ) are smaller than most other A. boreas toads. According to the literature, the SVL of A. boreas adults ranges from 56 to $125 \mathrm{~mm}$, A. b. boreas adults from 56 to $125 \mathrm{~mm}$ (Wright and Wright 1949), and A. boreas halophilus adults from 51 to $127 \mathrm{~mm}$ (Stebbins 2003). Interestingly, individuals of $A$. exsul, which are also geographically restricted and isolated, are diminutive as well (average SVL $=51.1$ mm; Murphy et al. 2003).

Further research is needed to elucidate the species boundaries and complex evolutionary relationships within the $A$. boreas species group (Dodd 2013). Significant differences in phenotypes (e.g., morphology, behavior, life history, or ecology) and environments may reflect local adaptations that should be used in evaluating the taxonomic statuses of populations in combination with genetic evidence (Haig et al. 2006). Other studies have shown discrepancies between the mitochondrial and nuclear data sets of populations within the A. boreas species group (Goebel et al. 2009), possibly due to speciation as a result of recent vicariance followed by rapid local adaptation to the unique desert spring habitats. For example, it appears that the duration of isolation of $A$. canorus and A. exsul has been insufficient for the mitochondrial genome to achieve reciprocal monophyly with other members of the A. boreas species group, though their nuclear genomes are divergent (Switzer et al. 2009). Moreover, toads within the family Bufonidae, including species of Anaxyrus, are known for having an inordinate amount of hybridization and mitochondrial introgression, emphasizing the need to analyze specimens using phenotypic diagnoses and nuclear and mitochondrial sequences (Pereyra et al. 2016).

Estimates of divergence times that were derived from mtDNA sequence similarities among the major A. boreas clades are consistent with hypotheses of Pleistocene divergences and suggest that major groups began diverging from each other in the early to mid Pleistocene and minor groups began diverging after that (Goebel et al. 2009). Wetter periods in the past may have allowed toads to access regions that are presently geographically isolated by deserts, such as $A$. exsul in eastern California, A. nelsoni in southwestern Nevada, and the DVT in central Nevada. Climate change at the end of the Pleistocene led to drier conditions, and these basins became hydrologically isolated (Reheis et al. 2002), which may have resulted in several vicariant events for populations of toads from the A. boreas species group (Hovingh 1997, Noles 2010). The entire extant population of DVTs relies on 4 wetlands fed by geothermal springs (Fig. 1), which are the only perennial sources of freshwater in its native habitat. Similarly, A. exsul occurs in only 4 isolated desert springs in the Deep Springs Valley of California (Fellers 2005), and A. nelsoni is currently restricted to several desert springs and portions of the Amargosa River within the Oasis Valley, Nevada (Altic and Dodd 1987, Goebel et al. 2005, Forrest et al. 2015). This geographic isolation, along with their morphological distinctiveness, are important reasons why $A$. nelsoni and A. exsul were designated as unique species (Stejneger 1893, Myers 1942, Simandle 2006). The effects of the desert environment and the limited dispersal tendencies of A. exsul resulted in fairly isolated populations with very low effective population sizes, all of which may have played a major role in its divergence and speciation from the A. boreas species group (Wang 2009).

The most immediate threat to the DVT appears to be the imminent expansion of the exploitation of nearby geothermal energy resources. Dixie Valley is one of the hottest $\left(>285{ }^{\circ} \mathrm{C}\right.$ at $3 \mathrm{~km}$ depth) and largest geothermal systems in the Basin and Range province, and has supported a $63-\mathrm{MW}$ power plant that has operated for over 20 years (Thakur et al. 2012). In 2012, the Nevada Bureau BLM approved an environmental assessment analyzing potential impacts associated with the proposed construction of up to 60 new geothermal exploration wells within Dixie Valley (BLM 2011). Additionally, sending groundwater from the Dixie Valley hydrographic area into the nearby Carson Desert is currently being considered (Huntington et al. 2014). Expanded exploitation of the geothermal and groundwater resources in the Dixie Valley could diminish or eliminate springs flowing to the wetlands, which may result in the disappearance of essential habitat for the DVT.

In 2008, a working group composed of the University of Nevada, Reno; Fallon Naval Air Station; USFWS; BLM; and NDOW began drafting a Candidate Conservation Agreement (CCA) because of concerns about activities 
on public federal lands that might affect the status of the DVT (K. Urquhart, personal communication 2016). Although the DVT does not currently fall under any formal classification for federal protection, it was anticipated that this conservation status could be addressed as a part of additional research and ongoing monitoring (Wildlife Action Plan Team 2012). Additionally, the cooperators signatory to the CCA support specific conservation actions geared toward identifying and reducing or eliminating threats to the DVT as well as maintaining and enhancing properly functioning ecosystems for the DVT (K. Urquhart, personal communication 2016). In 2013 the BLM, Carson City District, recommended that 413 acres of DVT habitat on BLM land should be considered as a potential Area of Critical Environmental Concern because it contains essential wildlife habitat for the DVT (BLM, CCD 2013; BLM 2014).

Our findings indicate that the Dixie Valley toad should be recognized as a distinct management unit. We recommend that rigorous monitoring of the Dixie Valley toad should continue because increased exploitation of hydrothermal energy and groundwater resources within Dixie Valley could eliminate essential aquatic habitat, which may result in extinction of this unique population of toads.

\section{Supplementary Materials}

Two online-only supplementary files accompany this article (scholarsarchive.byu.edu/ wnan/vol77/iss2/3).

Supplementary Material 1. Genetic diversity estimates for the Anaxyrus boreas populations based on microsatellite genotypes.

Supplementary Material 2. Heatmap showing pairwise $F_{\mathrm{ST}}$ values between sampling localities.

\section{ACKNOWLEDGMents}

We thank J.I. Carvajal for assistance with lab work and K. Urquhart, K. Tisdale, B. Bauman, T. Hawks, C. Byrne, K. Wright, M. Maples, C. Crookshanks (NDOW); B. Todd, O. Miano (UC Davis); and J. Harter (USFWS) for sample collections and field assistance. We also thank G.R. Cottle (NAS Fallon), R. Lovitch (DoD PARC), and J. Ennis and the Saval Family (McCoy Ranch) for permission, assistance, and access. Any use of trade, product, or firm names is for descriptive purposes only and does not imply endorsement by the U.S. government. Samples were collected under scientific collection permit number S-34992 issued by the Nevada Department of Wildlife for 2013.

\section{Literature Cited}

Altic, R., AND C.K. Dodd JR. 1987. The status of the Amargosa toad (Bufo nelsoni) in the Amargosa River drainage of Nevada. Southwestern Naturalist 32:276-278.

Baird, S.F., and C. GiRaRd. 1852. Descriptions of new species of reptiles, collected by the US exploring expedition under the command of Capt. Charles Wilkes, USN. Proceedings of the Academy of Natural Sciences of Philadelphia 6:174.

Baird, S.F., AND C. Girard. 1853. List of reptiles collected in California by Dr. John L. LeConte, with descriptions of new species. Proceedings of the Academy of Natural Sciences of Philadelphia 6:301.

[BLM] Bureau of Land Management. 2011. Environmental Assessment Ormat Technologies, Inc. Dixie Meadows Geothermal Exploration Project. DOI-BLM-NVC010-2011-0516-EA. http://prod-http-80-800498448 .us-east-1.elb.amazonaws.com/w/images/3/30/ DixieMeadows_FONSI_01_17_12.pdf

[BLM] BUREAU OF LAND MANGEMENT. 2014. Notice of availability of the Carson City District Draft Resource Management Plan and Draft Environmental Impact Statement, NV. Federal Register 79 [No. 229, Friday, November 28, 2014]:70892-70893. https://www.gpo.gov/fdsys/pkg/FR-2014-11-28/html/ 2014-28004.htm

[BLM, CCD] Bureau of Land Management, Carson City District. 2013. Carson City District Resource Management Plan Revision Areas of Critical Environmental Concern Report on the Application of the Relevance and Importance Criteria March 2013. https://eplanning.blm.gov/epl-front-office/projects/ lup/22652/42662/45450/ACEC-Report_CCDO final_Mar2013.pdf

CAmP, C.L. 1916. Description of Bufo canorus, a new toad from the Yosemite National Park. University of California Publications Zoology 17:59.

Caskey, S.J., and A.R. Ramelli. 2004. Tectonic displacement and far-field isostatic flexure of pluvial lake shorelines, Dixie Valley, Nevada. Journal of Geodynamics 38:131-145.

Davidson, C., AND G.M. Fellers. 2005. Bufo canorus Camp, 1916(a): Yosemite toad. Pages 400-401 in M.J. Lannoo, editor, Amphibian declines: the conservation status of United States species. University of California Press, Berkeley, CA.

DodD, C.K., JR. 2013. Frogs of the United States and Canada. Johns Hopkins University Press, Baltimore.

EARL, D.A., AND B.M. vONHOLDT. 2012. STRUCTURE HARVESTER: a website and program for visualizing STRUCTURE output and implementing the Evanno method. Conservation Genetics Resources 4:359-361.

Evanno, G., S. Regnaut, and J. Goudet. 2005. Detecting the number of clusters of individuals using the software STRUCTURE: a simulation study. Molecular Ecology 14:2611-2620. 
FALLON, S.M. 2007. Genetic data and the listing of species under the US Endangered Species Act. Conservation Biology 21:1186-1195.

Fellers, G.M. 2005. Bufo exsul Myers, 1942(a): Black toad. Pages 406-408 in M.J. Lannoo, editor, Amphibian declines: the conservation status of United States species. University of California Press, Berkeley, CA.

Forrest, M.J., M.S. Edwards, R. Rivera, J. SJÖberG, AND J. JAEGER. 2015. High prevalence and seasonal persistence of amphibian chytrid fungus infections in the desert-dwelling Amargosa toad, Anaxyrus nelsoni. Herpetological Conservation and Biology 10:917-925.

Forrest, M.J., K. Urquhart, J. Harter, O. Miano, and B. ToDD. 2013. Status of the Dixie Valley toad: first reports from population surveys and sampling for amphibian chytrid fungus Batrachochytrium dendrobatidis. Doctoral dissertation, University of California, San Diego, CA.

Garcia, C.A., J.M. Huntington, S.G. Buto, M.T. Moreo, J.L. Smith, And B.J. Andraski. 2014. Groundwater discharge by evapotranspiration, Dixie Valley, westcentral Nevada, March 2009-September 2011. U.S. Geological Survey Professional Paper 1805. http:// pubs.usgs.gov/pp/1805

Goebel, A.M., T.A. Ranker, P.S. Corn, and R.G. OlmSTEAD. 2009. Mitochondrial DNA evolution in the Anaxyrus boreas species group. Molecular Phylogenetics and Evolution 50:209-225.

Goebel, A.M., H.M. Smith, R.W. Murphy, and D.J. MorafKa. 2005. Bufo nelsoni Stejneger, 1893: Amargosa toad. Pages 427-430 in M.J. Lannoo, editor, Amphibian declines: the conservation status of United States species. University of California Press, Berkeley, CA.

Haig, S.M., E.A. Beever, S.M. Chambers, H.M. Draheim, B.D. Dugger, S. Dunham, E. Elliott-Smith, J.B. Fontaine, D.C. Kesler, B.J. Knaus, ET AL. 2006. Taxonomic considerations in listing subspecies under the US Endangered Species Act. Conservation Biology 20:1584-1594.

Hovingh, P. 1997. Amphibians in the eastern Great Basin (Nevada and Utah, USA): a geographical study with paleozoological models and conservation implications. Herpetological Natural History 5:97-134.

Huntington, J.M., C.A. Garcia, and M.R. Rosen. 2014. Hydrogeologic framework and occurrence, movement, and chemical characterization of groundwater in Dixie Valley, west-central Nevada. U.S. Geological Survey Scientific Investigations Report 2014-5152. http://pubs.usgs.gov/sir/2014/5152/pdf/ sir2014-5152.pdf

Karlstrom, E.L. 1958. Sympatry of the Yosemite and western toads in California. Copeia 1958:152-153.

Karlstrom, E.L. 1962. The toad genus Bufo in the Sierra Nevada of California: ecological and systematic relationships. University of California Publications. Zoology 62:1-104.

Kopelman, N.M., J. Mayzel, M. Jakobsson, N.A. RosenBERG, AND I. MAYROSE. 2015. Clumpak : a program for identifying clustering modes and packaging population structure inferences across $K$. Molecular Ecology Resources 15:1179-1191.

Meirmans, P.G., and P.H. Van Tienderen. 2004. GENOTYPE and GENODIVE: Two programs for the analysis of genetic diversity of asexual organisms. Molecular Ecology Notes 4:792-794.
Moritz, C. 1994. Defining 'evolutionarily significant units' for conservation. Trends in Ecology and Evolution 9:373-375.

Murphy, J.F., E.T. Simandle, and D.E. Becker. 2003. Population status and conservation of the black toad, Bufo exsul. Southwestern Naturalist 48:54-60.

Myers, G.S. 1942. The black toad of Deep Springs Valley, Inyo County, California. Occasional Papers of the Museum of Zoology, University of Michigan 460:3-13 [including plates I-III].

NoLES, P.M. 2010. Reconciling western toad phylogeography with Great Basin prehistory. Master's thesis, University of Nevada, Reno.

Palsbøll, P.J., M. Berube, and F.W. Allendorf. 2007. Identification of management units using population genetic data. Trends in Ecology and Evolution 22: $11-16$.

Pauly, G.B., D.M. Hillis, and D.C. Cannatella. 2009. Taxonomic freedom and the role of official lists of species names. Herpetologica 65:115-128.

Pereyra, M.O., D. Baldo, B.L. Blotto, P.P. Iglesias, M.T.C. Thomé, C.F.B. Haddad, C. Barrio Amorós, R. IbáÑEZ, AND J. Faivovich. 2016. Phylogenetic relationships of toads of the Rhinella granulosa group (Anura: Bufonidae): a molecular perspective with comments on hybridization and introgression. Cladistics 32:36-53.

Pritchard, J.K., M. Stephens, and P. Donnelly. 2000. Inference of population structure using multilocus genotype data. Genetics 155:945-959.

Reheis, M.C., A.M. Sarna-Wojcicki, R.L. Reynolds, C.A. Repenning, AND M.D. Mifflin. 2002. Pliocene to Middle Pleistocene lakes in the western Great Basin: ages and connections. Pages 53-108 in R. Hershler, D.B. Madsen, and D.R. Currey, editors, Great Basin Aquatic Systems History. Smithsonian Institution Press, Washington, DC.

Rose, J.P., O.J. Miano, G.R. Cottle, R.E. Lovich, R.L. Palmer, and B.D. TodD. 2015. A herpetological inventory of Naval Air Station Fallon, Churchill County, Nevada. Western North American Naturalist 75:526-534.

Shaffer, H.B., G.M. Fellers, A. Magee, and S.R. Voss. 2000. The genetics of amphibian declines: population substructure and molecular differentiation in the Yosemite toad, Bufo canorus (Anura, Bufonidae) based on single strand conformation polymorphism analysis (SSCP) and mitochondrial DNA sequence data. Molecular Ecology 9:245-257.

Shaffer, H.B., M. Gidi, E. McCartney-Melstad, K.M. Neal, H.M. Oyamaguchi, M. Tellez, and E.M. TofFELMIER. 2015. Conservation genetics and genomics of amphibians and reptiles. Annual Review of Animal Biosciences 3:113-138.

Silvestro, D., and I. Michalak. 2012. raxmlGUI: a graphical front-end for RAxML. Organisms Diversity and Evolution 12:335-337.

Simandle, E.T. 2006. Population structure and conservation of two rare toad species (Bufo exsul and Bufo nelsoni) in the Great Basin, USA. Doctoral dissertation, University of Nevada, Reno, NV.

Simandle, E.T., M.M. Peacock, L. Zirelli, and C.R. Tracy. 2006. Sixteen microsatellite loci for the Bufo boreas group. Molecular Ecology Notes 6: 116-119.

StamataKis, A. 2006. RAxML-VI-HPC: maximum likelihood-based phylogenetic analyses with thousands 
of taxa and mixed models. Bioinformatics 22 : 2688-2690.

Stebirins, R.C. 2003. A field guide to western reptiles and amphibians. 3rd edition. Houghton Mifflin Company, Boston, MA.

Stejneger, L. 1893. Annotated list of the reptiles and batrachians collected by the Death Valley Expedition in 1891, with descriptions of new species. North American Fauna, pp. 159-228.

Switzer, J.F., R. Johnson, B.A. Lubinski, AND T.L. King. 2009. Genetic structure in the Anaxyrus boreas species group (Anura, Bufonidae): an evaluation of the Southern Rocky Mountain population. United States Fish and Wildlife Service, Mountain Prairie Region. https://pubs.er.usgs.gov/publication/70043458

TAKEZaKi, N., M. NeI, and K. TAMura. 2014. POPTREEW: web version of POPTREE for constructing population trees from allele frequency data and computing some other quantities. Molecular Biology and Evolution 31:1622-1624.
Thakur, M., D.D. Blackwell, and K. Erkan. 2012. The regional thermal regime in Dixie Valley, Nevada, USA. Geothermal Resources Council Transactions 36:59-67. WANG, I.J. 2009. Fine-scale population structure in a desert amphibian: landscape genetics of the black toad (Bufo exsul). Molecular Ecology 18:3847-3856.

Wildlife Action Plan Team. 2012. Nevada Wildlife Action Plan. Nevada Department of Wildlife, Reno, NV. http://www.ndow.org/Nevada_Wildlife/Conser vation/Nevada_Wildlife Action_Plan

Wright, A.H., AND A.A. Wright. 1949. Handbook of frogs and toads of the United States and Canada. 3rd edition. Cornell University Press, Ithaca, NY.

Received 20 September 2016

Accepted 28 February 2017

Published online 19 May 2017 